\title{
Silicates, Silicate Weathering, and Microbial Ecology
}

\author{
P. C. BENNETT \\ J. R. ROGERS \\ W. J. CHOI \\ Department of Geological Sciences \\ The University of Texas at Austin \\ Austin, Texas, USA
}

\section{F. K. HIEBERT}

RMT Inc.

Austin, Texas, USA

\begin{abstract}
Mineralogy, microbial ecology, and mineral weathering in the subsurface are an intimately linked biogeochemical system. Although bacteria have been implicated indirectly in the accelerated weathering of minerals, it is not clear if this interaction is simply the coincidental result of microbial metabolism, or if it represents a specific strategy offering the colonizing bacteria a competitive ecological advantage. Our studies provide evidence that silicate weathering by bacteria is sometimes driven by the nutrient requirements of the microbial consortium, and therefore depends on the trace nutrient content of each aquifer mineral. This occurrence was observed in reducing groundwaters where carbon is abundant but phosphate is scarce; here, even resistant feldspars are weathered rapidly. This suggests that the progression of mineral weathering may be influenced by a mineral's nutritional potential, with microorganisms destroying only beneficial minerals. The rock record, therefore, may contain a remnant mineralogy that reflects early microbial destruction of biologically valuable minerals, leaving a residuum of "useless" minerals, where "value" depends on the organism, its metabolic needs, and the diagenetic environment. Conversely, the subsurface distribution of microorganisms may, in part, be controlled by the mineralogy and by the ability of an organism to take advantage of mineral-bound nutrients.
\end{abstract}

Keywords microbial geochemistry, phosphate, silicate weathering

Interest in the microbial ecology of subsurface environments has grown tremendously in the past 10 years, and viable microorganisms have been recovered from a wide range of subsurface environments (Ghiorse and Wilson 1988; Chapelle and Lovley 1990; Madsen and Ghiorse 1993; Ehrlich 1996a; Madigan, Martinka, and Parker 1997; Sharp, Parkes, Cragg, Fairchild, Lamb, and Tranter 1999). The by-products of microbial metabolism, however, are geochemically reactive, and there is increasing evidence of a direct link between the microbial ecology and the geochemistry of an aquifer (Fredrickson, Garland, Hicks,

Received 31 August 2000; accepted 25 September 2000.

We gratefully acknowledge the assistance and contributions of G. Delin and W. Herkelrath (U.S. Geological Survey) and William Ullman (University of Delaware). This research was supported by the National Science Foundation GERT program, American Chemical Society Petroleum Research Fund, U.S. Geological Survey Toxic Hydrology Program, and the Geology Foundation of The University of Texas at Austin.

Address correspondenc e to P. C. Bennett, Department of Geological Sciences, University of Texas at Austin, Austin, TX 78712, USA. E-mail: pbennett@mail.utexas.ed u 
Thomas, Li, and McFadden 1989; Pedersen 1993; Lovley and Chapelle 1995), including the accelerated dissolution of silicates (Vandevivere, Welch, Ullman, and Kirchman 1994; Ullman, Kirchman, Welch, and Vandevivere 1996; Barker, Welch, Chu, and Banfield 1998). These observations, however, raise a fundamental question: Does the enhanced weathering of a mineral by microorganisms offer an advantage to that population, or is it simply a coincidental by-product of metabolism? We propose that microorganisms in the typically nutrient-limited subsurface ecosystem promote, and directly benefit from, the weathering of specific minerals.

\section{Subsurface Microbial Ecology}

Heterotrophic organisms gain energy from a proton motive force (PMF) generated by the transfer of electrons from a reduced carbon substrate to an electron acceptor. In oxic systems, aerobes utilize molecular oxygen as the electron acceptor, while $\mathrm{NO}_{3}^{-}, \mathrm{Fe}^{(\mathrm{III})}$, and $\mathrm{SO}_{4}{ }^{2-}$ can be utilized by anaerobes when oxygen is absent (e.g., Chapelle 1993; Ehrlich 1996a; Madigan et al. 1997). Most organisms also require nitrogen and phosphoru s for cell growth and metabolism, and these nutrients are often limiting in groundwater systems, especially phosphorus. There are also a number of other necessary micronutrients that can limit microbial growth and metabolism in some systems, such as potassium or magnesium, although these are typically available even in dilute groundwaters. In an organic-rich groundwater, therefore, phosphorus and nitrogen often become the limiting macronutrients (henceforth "nutrients"), and microbial strategies that increase their bioavailability would enhance the survival of the native consortium.

In many groundwater systems, soluble phosphate $\left(\mathrm{PO}_{4}{ }^{3-}\right.$, or simply "P") is scarce and tightly cycled within the microbial community, potentially limiting growth of the indigenous microorganisms (Ghiorse and Wilson 1988; Madsen and Ghiorse 1993; Madigan et al. 1997). All organisms require $P$ for ATP and nucleotide production and biomass addition, and many organisms have evolved biochemical strategies for extracting mineral-bound $\mathrm{P}$ from such sources as hydrous Al- or Fe-phosphates by the production of acids or chelating ligands or the reduction of $\mathrm{Fe}$ (III) to soluble $\mathrm{Fe}^{2+}$ (Goldstein 1986; Halder and Chakrabartty 1993; Babu-Khan, Yeo, Martin, Duran, Rogers, and Goldstein 1995). Iron reducers, which utilize mineral ferric iron as a terminal electron (Lovley, Baedecker, Lonergan, Cozzarelli, Phillips, and Siegel 1989; Albrechtsen 1994), may release P from iron oxides and hydroxides secondary to reductive dissolution (Jansson 1987).

As dissolved orthophosphate in groundwater becomes increasingly scarce, the microbial consortia must scavenge it from poorly soluble minerals such as apatite (Goldstein 1986) or even apatite inclusions in silicates, and the organism best able to obtain $P$ will dominate the consortia. Our research suggests that attached microorganisms produce a very reactive microenvironment at the mineral surface that accelerates the dissolution of silicate minerals, releasing limiting $\mathrm{P}$ and $\mathrm{Fe}$, which offers the colonizing organism a competitive advantage. This results in a selective increase in biomass and productivity of the attached bacteria at the expense of the mineral framework.

\section{Mechanisms of Feldspar Weathering}

To enhance the release of mineral nutrients from feldspars, microorganisms must accelerate the dissolution of the silicate matrix, thus exposing fresh nutrient for release and uptake. There are, however, a limited number of mechanisms that can be perturbed to produce accelerated feldspar weathering. The general model of feldspar dissolution in abiotic inorganic aqueous systems involves a multistep process of (1) initial rapid exchange of 
charge-balancing cations $\left(\mathrm{K}^{+}, \mathrm{Na}^{+}\right.$, and/or $\left.\mathrm{Ca}^{2+}\right)$ for protons at the mineral surface; (2) slow, rate-determining hydrolysis and formation of an activated complex; and (3) detachment of silica and alumina species from the remaining framework and exposure of fresh surface for reaction (Wollast 1967; Aagaard and Helgeson 1982; Helgeson, Murphy, and Aagaard 1984). The rate of this generalized reaction mechanism will be a function of temperature, pressure, ionic strength, proton and hydroxyl concentration, and the presence of chelating ligands, and these are the possible variables available for a microorganism to perturb.

\section{pH Dependence of Feldspar Dissolution}

The dissolution rate of feldspars is a complex function of $\mathrm{pH}$ with a rate minima at circumneutral $\mathrm{pH}\left\{r=k_{+}\right\}$, and faster dissolution with increasing proton $\left\{r=k_{+}\left(a_{\mathrm{H}^{+}}\right)^{m}\right\}$ and increasing hydroxyl concentrations $\left\{r=k_{+}\left(a_{\mathrm{OH}^{-}}\right)^{n}\right\}$ (e.g., Wollast and Chou 1992; Hellman 1994), where $r$ is the net dissolution rate, $k_{+}$is the forward rate constant, and $a_{\mathrm{H}^{+}}$and $a_{\mathrm{OH}^{-}}$ is the activity of proton and hydroxyl, respectively.

In simple solutions, variations in hydrolysis rate with $\mathrm{pH}$ are probably controlled by the acid-base properties of bridging oxygens or terminal hydroxyl oxygens at the mineral surface (Casey and Bunker 1990). The acid-base reactions on the mineral surfaces are synonymous with the sorption of hydroxyl or hydrogen ions onto the oxide surface. The surface concentration of both proton and hydroxyl can be significantly altered near surfaceadhering microorganisms or under biofilms.

\section{Temperature, Pressure, and Ionic Strength}

Temperature and pressure are fundamental controls of the rate of chemical reactions. Although at earth surface conditions, pressure is not generally a significant influence on silicate weathering reactions in solution, reaction rates can vary by several orders of magnitude over a $100^{\circ} \mathrm{C}$-temperature range (e.g., Lasaga 1981; Laidler 1987). The temperature dependence of the dissolution rate constant can be evaluated using the empirically derived Arrhenius relationship, $k_{r}=A e^{-E_{a} R T}$, where $k_{r}$ is the dissolution rate constant, $A$ is a pre-exponential frequency factor, $E_{a}$ is the activation energy, $R$ is the gas constant, and $T$ is the absolute temperature. However, although temperature is an important variable to consider in feldspar weathering kinetics, particularly with experimental determinations of rate, the ability of a microorganism to significantly vary temperature at the mineral surface is probably slight.

At neutral to acidic $\mathrm{pH}$, increasing ionic strength (I) increases the dissolution rate of silica (Tadros and Lyklema 1968; Abendroth 1970), quartz (Dove and Crerar 1990; Bennett 1991), and $\gamma-\mathrm{Al}_{2} \mathrm{O}_{3}$ (Huang 1981). In contrast, feldspar dissolution rate decreases with increasing ionic strength, probably by inhibiting the critical ion exchange reaction at the feldspar surface (Stillings and Brantley 1995; Brantley and Stillings 1996). Around attached microorganisms or biofilms there may be a significant change in ionic strength compared with the bulk solution (Chenu and Roberson 1996), but it is difficult to suggest a mechanism for decreasing ionic strength to affect an increase in dissolution rate and release of nutrient.

\section{Organic Ligands}

Microbially produced organic ligands include metabolic by-products, extracellular enzymes, chelates, and both simple and complex organic acids. These substances can influence feldspar dissolution rates either by decreasing $\mathrm{pH}$, by forming framework-destabilizing surface complexes, or by complexing metals in solution.

Many investigators have found that organic acids enhance the dissolution of aluminosilicate minerals or quartz both in field observations and from laboratory experiments 
(Grandstaff 1986; Surdam and MacGowan 1988; Huang and Longo 1992; Welch and Ullman 1993; Bennett and Casey 1994; Drever and Vance 1994; Blake and Walter 1996; Stillings, Drever, Brantley, Sun, and Oxburgh 1996). Welch and Ullman (1993) found that the rates of plagioclase dissolution in solutions containing organic acids were up to 10 times greater than the rates in solutions containing inorganic acids at the same acidity. Steady-state rates of dissolution were highest (up to $1.3 \times 10^{-12} \mathrm{~mol} / \mathrm{cm}^{2} / \mathrm{sec}$ ) in acidic solutions $(\mathrm{pH} \sim 3$ ) and decreased (to $1 \times 10^{-15} \mathrm{~mol} / \mathrm{cm}^{2} / \mathrm{sec}$ ) as acidity decreased toward neutral $\mathrm{pH}$. The polyfunctional acids - oxalic, citric, succinic — and 2-ketoglutaric acids were the most effective at promoting dissolution.

\section{Biogeochemistry of Silicate Weathering}

Microorganisms alter mineral solubility and dissolution kinetics both indirectly, by perturbing bulk groundwater chemistry, and directly when attached microorganisms perturb mineral-water equilibria and reaction dynamics at the point of attachment and growth (e.g., Ehrlich 1996b). Fungi, for example, solubilize silicates by the production of both mineral and organic acidity (Eno and Reuzer 1955; Silverman and Munoz 1970; Avakyan, Karavaiko, Mel'nikova, Krutsko, and Ostroushko 1981; Callot, Maurette, Pottier, and Dubois 1987), thus releasing critical nutrients (e.g., Jongmans, van Breeman, Lundstrom, van Hees, Finlay, Srinivasan et al. 1997), yet the complexation of released $\mathrm{Al}^{3+}$ reduces phytotoxicity (Kinraide 1991). Fungi have been found to excrete higher concentrations of more effective chelating agents than, for example, bacteria (Palmer, Siebert, and Hirsch 1991). However, bacteria are more prolific and exist in extreme environments that fungi cannot tolerate. Lichen, a symbiotic association between fungi and algae, has been shown to weather rock in situ (Jones, Wilson, and McHardy 1981), and Barker and Banfield (1996) found that lichen weathered syenite.

Bacteria have also been shown to accelerate the dissolution of silicates by the production of excess proton and organic ligands, and in some cases by the production of hydroxyl anion, extracellular polysaccharides (EPS), and enzymes (Berthelin and Belgy 1979; Malinovskaya, Kosenko, Votselko, and Podgorskii 1990; Hiebert and Bennett 1992; Welch and Ullman 1993; Vandevivere et al. 1994; Barker et al. 1998). Welch, Barker, and Banfield (1999) found that a variety of extracellular polysaccharides significantly enhanced the dissolution of plagioclase at $\mathrm{pH} 4$ but had little effect at $\mathrm{pH}$ 7. EPS can also act as a nucleation site for authigenic mineral formation (Barker and Hurst 1992; Urrutia and Beveridge 1994, 1995; Barker and Banfield 1996; Fortin, Ferris, and Beveridge 1997; Barker et al. 1998). Increasing evidence also exists for a mechanism of direct silicate precipitation by bacteria via metal sorption at the cell membrane (Beveridge and Murray 1980; Beveridge and Fyfe 1985; Ferris, Schultze, Witten, Fyfe, and Beveridge 1989; Urrutia and Beveridge 1994; Konhauser and Ferris 1996). The precipitation of carbonate minerals coupled to calcium silicate weathering has been suggested as a mechanism of global $\mathrm{CO}_{2}$ buffering (Berner, Lasaga, and Garrells 1983) but has also been documented in the field. Ferris, Wiese, and Fyfe (1994) found that cyanobacteria serve as nucleation sites for carbonate minerals related to the weathering of basalt.

\section{EXPERIMENTAL APPROACH}

Characterizing the interaction of attached microorganisms on a silicate surface in situ is problematic. A typical groundwater is nutrient- and/or carbon-limited with low titer $\left(10^{1}-10^{5}\right.$ cells $\left./ \mathrm{ml}\right)$, and very low yield coefficients (Chapelle and Lovley 1990; Bekins, Godsy, and Warren 1999). Sand grains collected from the target aquifer have often been 
subject to multiple episodes of physical and chemical weathering, resulting in a complex history of surface alteration, making it difficult to unambiguously distinguish the influence of microorganisms.

To characterize the influence of microorganisms on silicate weathering, we use in situ microcosms (Hiebert and Bennett 1992) to characterize microbial colonization and mineral weathering in field settings, with adjunct laboratory-microcosm experiments used to examine substrate utilization and by-product production. The field methods have been described in detail elsewhere (Hiebert and Bennett 1992; Rogers, Bennett, and Choi 1998). Briefly, clean, sterile mineral chips are placed in permeable polyethylene chambers, and these chambers are suspended in wells, or buried, in the target aquifer for periods of months to years. Upon recovery, biological tissues are fixed using chemical critical-point drying (Vandevivere and Bevaye 1993). Fixed samples are inspected in the laboratory using conventional scanning electron microscopy (C-SEM) with an accelerating voltage of $30 \mathrm{kV}$, and environmental SEM (E-SEM) for microbial abundance, colonization pattern, and etch pit or mineral precipitate development.

Mineral and rock specimens were characterized using light microscopy, electron microprobe analysis, trace metal analysis, and whole rock analysis. For microprobe analysis, the thin sections were carbon-coated, imaged, and probed using an accelerating voltage of $15 \mathrm{kV}$ and a sample current of $15 \mathrm{nA}$. Both the silicate groundmass and the accessory minerals were examined to determine composition. Major element oxides were determined by XRF and trace elements by ICP-OES (Activation Laboratories, Ontario, Canada). Results have been described previously (Hooper and Hawkesworth 1993; Rogers et al. 1998) and are summarized in Table 1.

TABLE 1 Whole rock and trace element analysis of rocks, minerals

\begin{tabular}{lcccccccc}
\hline \multicolumn{1}{c}{ Element } & Anor & SD-Micr & Olig & O-Micr & Plag & Qtz & Bst & Oliv \\
\hline $\mathrm{SiO}_{2}(\%)$ & 60.63 & 65.17 & 62.97 & 66.93 & 59.8 & 99.78 & 51.0 & 40.75 \\
$\mathrm{Al}_{2} \mathrm{O}_{3}(\%)$ & 19.08 & 18.38 & 22.72 & 17.62 & 20.87 & 0.08 & 13.65 & 0.2 \\
$\mathrm{Fe}_{2} \mathrm{O}_{3}(\%)$ & 4.41 & 0.9 & 1.3 & 1.78 & 1.07 & 0.02 & 14.12 & 9.73 \\
$\mathrm{MgO}(\%)$ & 0.93 & 0.01 & 0.03 & 0.04 & 0.08 & $<0.01$ & 4.54 & 50.75 \\
$\mathrm{CaO}(\%)$ & 3.04 & 0.15 & 4.51 & 0.14 & 2.37 & 0.01 & 8.93 & 0.07 \\
$\mathrm{Na}_{2} \mathrm{O}(\%)$ & 6.62 & 2.18 & 8.16 & 2.41 & 6.69 & $<0.01$ & 2.67 & $<0.01$ \\
$\mathrm{~K}_{2} \mathrm{O}(\%)$ & 3.99 & 13.5 & 0.6 & 11.88 & 7.37 & 0.03 & 1.07 & 0.01 \\
$\mathrm{TiO}_{2}(\%)$ & 0.93 & $<0.01$ & $<0.01$ & 0.01 & $<0.01$ & $<0.01$ & 3.11 & 0.01 \\
$\mathrm{P}(\mathrm{ppm})$ & 1050 & 1225 & 130 & $<50$ & $<50$ & 90 & 3010 & $<50$ \\
$\mathrm{Ba}(\mathrm{ppm})$ & 1130 & 36 & 51 & 102 & 438 & $<2$ & 505 & 3 \\
$\mathrm{Zr}(\mathrm{ppm})$ & 243 & $<2$ & 1 & $<2$ & $<2$ & $<2$ & 175 & $<2$ \\
$\mathrm{Cu}(\mathrm{ppm})$ & 10 & 7 & 11 & 11 & 6 & 8 & 24 & 7 \\
$\mathrm{~Pb}(\mathrm{ppm})$ & 5 & 133 & 46 & 137 & 28 & $<5$ & 6.2 & 5 \\
$\mathrm{Zn}(\mathrm{ppm})$ & 96 & 2 & 6 & 3 & 3 & 2 & 126 & 36 \\
$\mathrm{Ni}(\mathrm{ppm})$ & 36 & 4 & 19 & 5 & 2 & 14 & 85 & 2796 \\
$\mathrm{Mn}(\mathrm{ppm})$ & 841 & 48 & 106 & 85 & 57 & 73 & 896 & 802 \\
$\mathrm{Sr}(\mathrm{ppm})$ & 612 & 73 & 230 & 40 & 399 & 5 & 314 & 2 \\
$\mathrm{~V}(\mathrm{ppm})$ & 42 & 2 & 2 & 2 & 2 & 2 & 431 & 2 \\
$\mathrm{Y}(\mathrm{ppm})$ & 35 & 2 & 2 & 2 & 2 & $<2$ & 42 & $<2$ \\
\hline
\end{tabular}

Minerals/Rocks analyzed are anorthoclase (Anor), S. Dakota microcline (SD-Micr), Oligoclase (Olig) Ontario microcline (O-Micr), plagioclase (Plag), quartz (Qtz) (Rogers et al. 1998), basalt (Bst) (Hooper and Hawkesworth 1993), and olivine (Oliv). 


\section{Field Studies}

Our primary field study site is a petroleum-contaminated aquifer near Bemidji, Minnesota, where dissolved hydrocarbons (principally the soluble aromatic compounds) are rapidly degraded. Hydrocarbon s in the anoxic region under the floating oil pool are biodegraded primarily by iron (III) reduction (Lovley et al. 1989; Baedecker, Cozzarelli, Siegel, Bennett, and Eganhouse 1993; Bekins et al. 1999) and by secondary methanogenesis (Revesz, Coplen, Baedecker, Glynn, and Hult 1995) of produced organic acids. Degradation of the contaminating petroleum has produced a plume of inert and reactive organic and inorganic solutes, including a variety of organic acids (Cozzarelli, Baedecker, Eganhouse, and Goerlitz 1994), and etching of native quartz and feldspar grains has been documented (Bennett, Siegel, Baedecker, Cozzarelli, and Hult 1993).

Parallel studies were carried out in the Glacial Lake Agassiz Peatlands to examine microbial colonization and silicate weathering in a geochemically similar (high concentrations of dissolved carbon under anoxic conditions) but uncontaminated site. The study site was in the boreal Lost River peatland, part of an expansive mire that has developed over the bed of glacial Lake Agassiz, northern Minnesota. Here, peat has accumulated to an average depth of 3 meters, with a variety of hydrologic and geochemical regimes developing. In a comparison of a spring fen (groundwater discharge zone) and a raised bog (groundwater recharge zone) (Bennett, Siegel, Hill, and Glaser 1990; Glaser, Bennett, Siegel, and Romanowicz 1996) circum-neutral oxic conditions were found throughout the spring fen profile as groundwater discharged to the surface. The raised bog, in contrast, incorporated two distinct geochemical zones, an oxic and acidic surface zone and an anoxic circum-neutral deep zone, with groundwater flowing from acidic to neutral. Significant methanogenesis occurs in the deeper portion of the bog, less in the shallow bog, and is almost absent in the fen, with minor iron reduction in the bog.

Geochemical parameters, including dissolved carbon, nutrients, anions, cations, and field parameters were determined from samples collected at the time of microcosm placement and recovery using standard methods (Bennett et al. 1993). Total biomass on microcosm minerals and in the water was determined as the total lipid biomass, and microbial diversity on mineral surfaces was estimated from SEM-imaged cell morphology, phospholipid fatty acid analysis, and 16srRNA DGGE (denaturing gradient gel electrophoresis) analysis (Microbial Insights, Inc., Rockford, TN). Diversity on mineral chips was also characterized by enrichment culture techniques using PRAS (prereduced, anaerobically sterilized) prepared media appropriate for methanogens, iron reducer, and fermenters. These bottles were allowed to incubate for 1 to 6 weeks before they were scored using standard methods (Bekins et al. 1999).

\section{Laboratory Microcosms}

In addition to the field approach, laboratory microcosms of native consortia were constructed using clean reference-mineral fragments inoculated with aquifer materials (sand or peat) and groundwater from the field sites. Cores were collected from the microbially active anoxic region of the contaminated Bemidji aquifer using a frozen-shoe, wire-line core barrel (Murphy and Herkelrath 1996). The core material and the selected mineral type were transferred to triplicate sterile serum bottles in an anaerobic chamber, finished with a 1:1 mixture of formation water and sterile anaerobic water, and amended with toluene. Peat and peat-water were collected from shallow piezometers using a peristaltic pump. Dead and uninfected control samples were also constructed, and split samples of sediments were collected for microbial identification and standard geochemical analyses. Reaction progress was determined by the periodic withdrawal and chemical characterization of 1-ml sample aliquot. 
TABLE 2 Summary results from in situ microcosm minerals after exposure to oil-contaminated groundwater and laboratory microcosms after incubating with peat

\begin{tabular}{|c|c|c|c|c|c|}
\hline \multirow[b]{2}{*}{ Mineral } & \multicolumn{2}{|c|}{ In situ microcosms } & \multicolumn{3}{|c|}{ Peat microcosms } \\
\hline & Colonized & Weathered & Colonized & Weathered & Si-release \\
\hline Anorthoclase & +++ & +++ & +++ & +++ & +++ \\
\hline P-microcline & + & + & ++ & - & \\
\hline Fe-microcline & - & - & - & - & \\
\hline Quartz & ++ & + & + & - & \\
\hline Olivine & - & - & $* *$ & $* *$ & $* *$ \\
\hline Basalt & +++ & +++ & $* *$ & $* *$ & $* *$ \\
\hline Oligoclase & + & + & $* *$ & $* *$ & $* *$ \\
\hline Plagoclase & - & - & $* *$ & $* *$ & $* *$ \\
\hline Apatite & + & ++ & - & ++ & - \\
\hline Magnetite & +++ & + & +++ & + & - \\
\hline
\end{tabular}

Increasing density of colonization, glycocalyx production, and mineral surface weathering are indicated by + through.+++- indicates that the feature was not observed. $* *$ indicates that mineral system was not examined.

\section{Observations and Interpretations}

In situ colonization experiments in the oil-contaminated aquifer, conducted over periods of 3 to 12 months, show a distinct pattern of colonization and weathering. A similarly distinct response is observed in laboratory microcosms with the addition of specific mineral chips. On quartz surfaces, the attached microbial consortium is relatively diverse, though sparse, with significant glycocalyx development (Table 2). Surfaces are lightly etched near the colonizing organisms, particularly under the glycocalyx (Hiebert and Bennett 1992). Large colonies are never found on the quartz surface, only individual organisms or small groups.

Ontario microcline, oligoclase, and plagioclase $\left(\sim \mathrm{An}_{40}\right)$ surfaces are all barren of microbiota, biofilm development, or chemical weathering (Table 2). None of these feldspars contained detectable $\mathrm{P}$, although they all contain $3000-6000 \mathrm{ppm} \mathrm{Fe}^{(\mathrm{III})}$. Oligoclase $\left(\sim \mathrm{An}_{25}\right)$ is lightly colonized with evidence of chemical weathering, and this specimen contains $\sim 130 \mathrm{ppm}$ P. Addition of these minerals to nutrient-limited laboratory microcosms does not influence toluene utilization rate or methane production (Table 2).

Anorthoclase and South Dakota microcline, with 1050 and 1220 ppm P and 12,000 and 2,500 $\mathrm{ppm} \mathrm{Fe}{ }^{(\mathrm{III})}$, respectively, are heavily colonized and weathered (Figures 1, 2). Initial colonization (observed after 3 months) is by a morphologically diverse consortium, with diversity decreasing over time (12 months) as mineral weathering progresses. On the microcline specimen, secondary clays (smectite?) are observed on uncolonized, unweathered mineral surfaces (Figure 3), while clays appear to nucleate and grow on the cell wall surface of organisms colonizing anorthoclase (Figure 1). The P in anorthoclase and microcline occurs as inclusions of bladed apatite (Rogers et al. 1998). Iron oxides are present in the anorthoclase while South Dakota microline does not contain iron-bearing accessory minerals.

Using the enrichment culture method, both anorthoclase and South Dakota microline recovered from the oil-contaminated aquifer scored positive for colonization by Fe reducers and fermenters. Analysis of the phospholipid fatty acids (PLFA; Microbial Insights, Inc., 


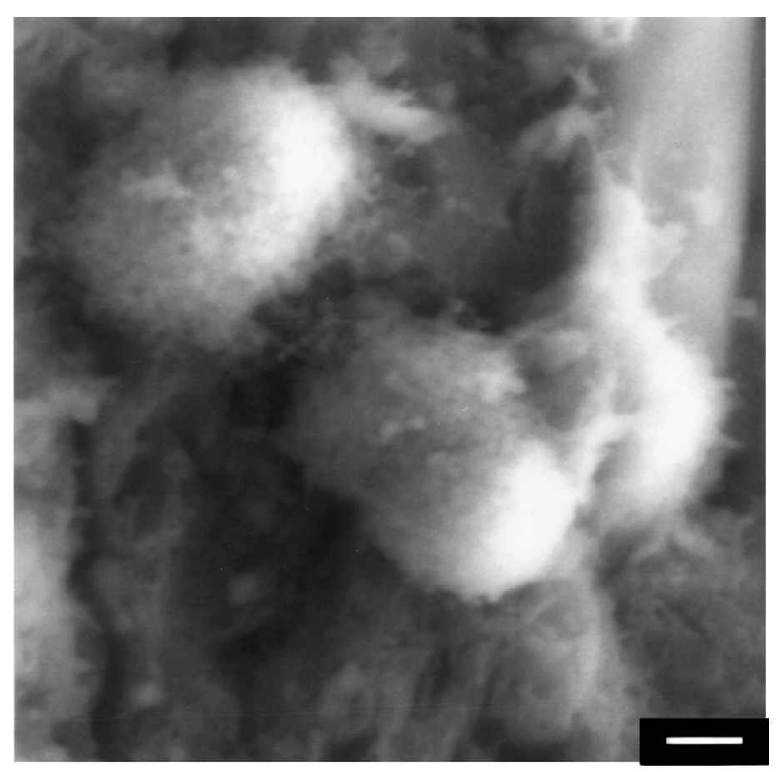

FIGURE 1 E-SEM image of anorthoclase surface after 1 year. Surface weathered and covered with cocci or diplococci, which are coated in a secondary clay precipitate. Scale bar $=1 \mu \mathrm{m}$.

Rockford, TN) shows that the water and sediment from that aquifer zone have similar microbial consortia dominated by gram-negative anaerobes, probably Geobacteracae and Geothrix (e.g., Rooney-Varga, Anderson, Fraga, Ringelberg, and Lovley 1999). The contaminated sediment in the anaerobic zone under the oil supports a specific lipid biomass

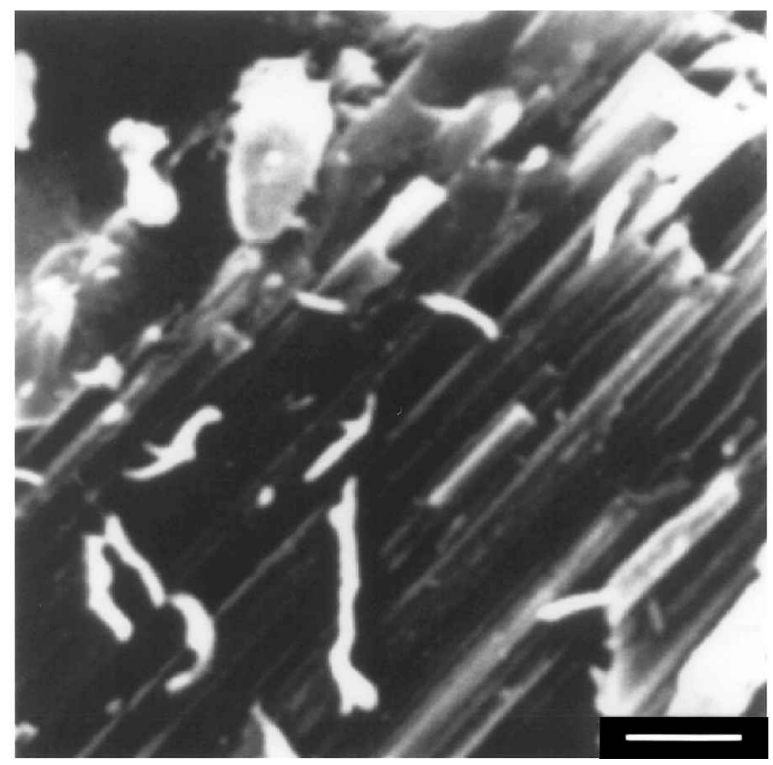

FIGURE 2 C-SEM image of South Dakota microcline surface after 1 year with deep etch features. Scale bar $=1 \mu \mathrm{m}$. 


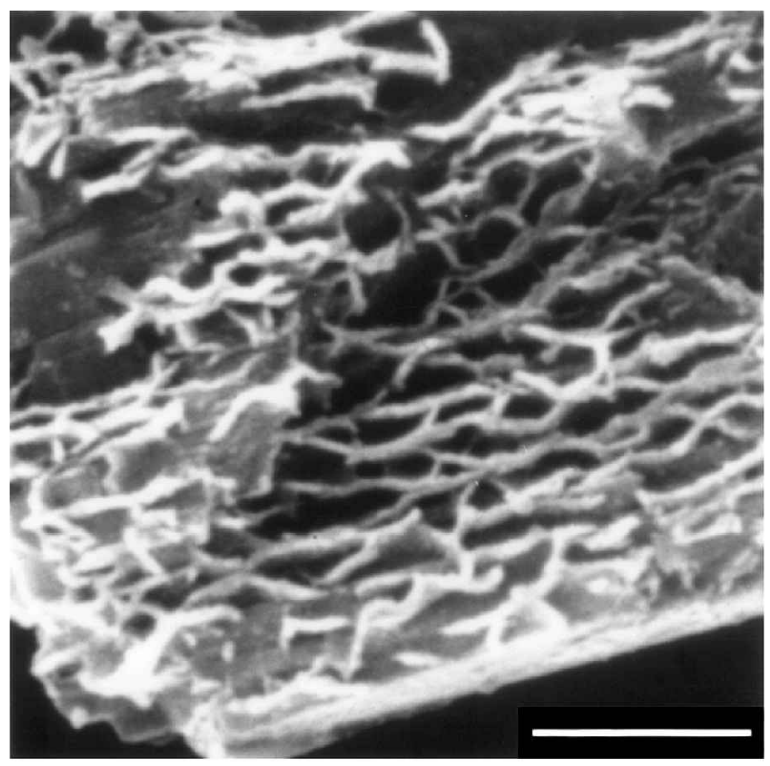

FIGURE 3 C-SEM image of uncolonized SD microcline surface with clay (smectite?) precipitation. Scale bar $=1 \mu \mathrm{m}$.

(cells per unit surface area) of approximately $10^{6} \mathrm{cell} / \mathrm{m}^{2}$. After 9 months in situ, a set of anorthoclase chips accumulated 10 to 20 times the specific biomass of the surrounding sediment, while the PLFA analysis suggests a decrease in diversity in the microbial consortium on the mineral surface. In laboratory microcosms using oil-contaminated sediment without nutrient addition, bottles amended with anorthoclase degraded toluene twice as fast as the SD-microcline bottle, and 5 times faster than the quartz microcosm. We theorize that the system is both $\mathrm{P}$-limited and possibly $\mathrm{Fe}^{(\mathrm{III})}$-limited to the iron-reducing organisms, which dominate the population. Both $\mathrm{P}$ and $\mathrm{Fe}^{(\mathrm{III})}$ are present in the anorthoclase, and available, while the SD- microcline contains only available $\mathrm{P}$.

Colonization is not observed on olivine after $>12$ months, and no indication of weathering was observed (Table 2). The olivine contains no detectable $\mathrm{P}$, and although there is $\mathrm{Fe}$, there are relatively high concentrations of other metals, particularly $\mathrm{Ni}(\sim 3000 \mathrm{ppm})$. It is possible that $\mathrm{Ni}$ acts as a biocide or in some other way influences the colonization behavior.

Extremely heavy colonization is observed on crystalline Columbia River basalt after only 3 months of exposure to the oil-contaminated groundwater (Figures 4-6). The basalt contains $\sim 3000$ ppm P occurring as apatite, but less than 100 ppm Ni. Only one morphotype is observed, and this organism attaches to the surface via filaments without a distinct glycocalyx layer. The appearance of this organism-mineral ecosystem appears to progress from a smooth cell attached to an unaltered mineral surface (Figure 4) to a slightly bumpy cell attached to a slightly pitted mineral surface (Figure 5) to an extremely distorted cell attached to an extremely etched mineral surface (Figure 6). Although this chip was in the aquifer for 3 months, we interpret a variable attachment time for organisms based on the attachment mechanism, apparent silicate weathering, and degree of mineral precipitation onto the cell. The last stage of this possible time line shows the attached organism to be extremely misshapen and possibly no longer viable.

The angular morphology of the material growing on the cell surface (Figure 6) suggests a crystal precipitate, rather than bacteriophage, budding, or some organic material. Considering that the pore-water is supersaturated with respect to calcite (Bennett et al. 1993), 


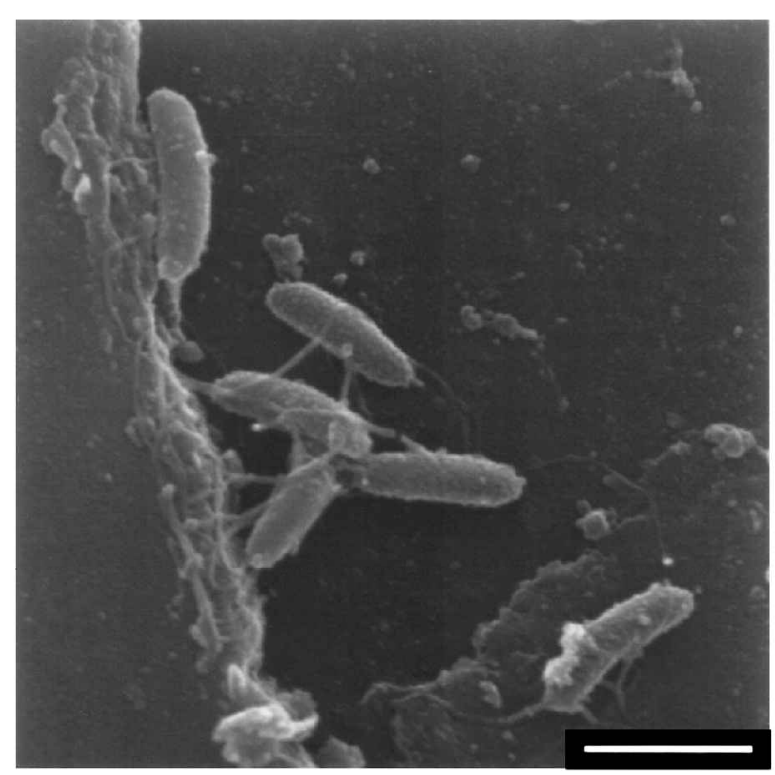

FIGURE 4 C-SEM image of basalt surface after 3 months with attached bacteria. Scale bar $=1 \mu \mathrm{m}$.

and dissolving basalt releases substantial $\mathrm{Ca}^{2+}(\mathrm{CaO} \%=8.93)$, we hypothesize that these precipitates are calcite. These putative calcite crystals cover a maximum of $\sim 50 \%$ of the exposed cell wall, at which point there appears to be loss of cell shape and integrity and no further addition of calcite. This suggests that mineral precipitation is only associated

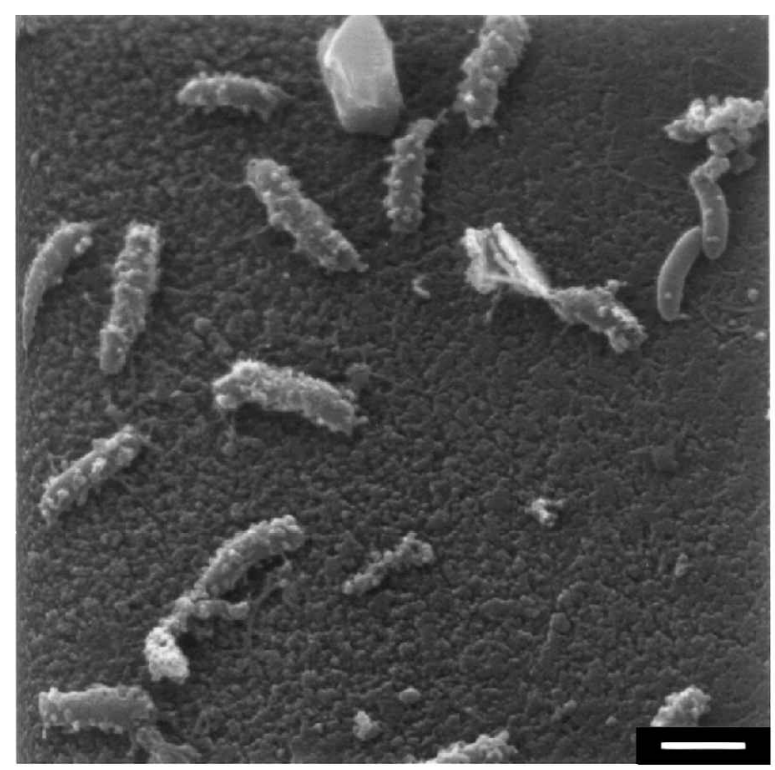

FIGURE 5 C-SEM image of basalt after 3 months with attached bacteria and evidence of general weathering of the surface and mineral precipitation on the organism's cell wall. Scale bar $=1 \mu \mathrm{m}$. 


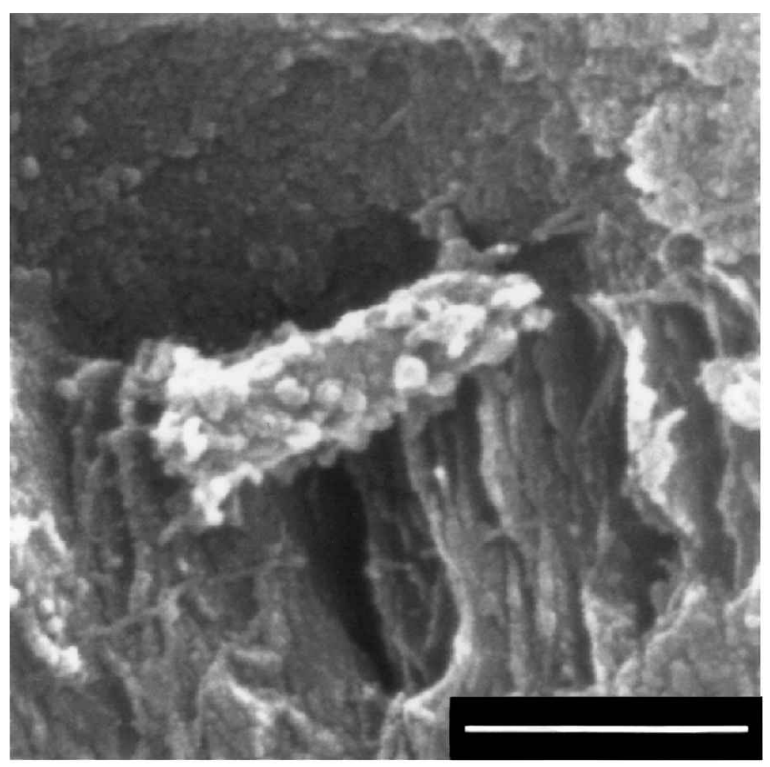

FIGURE 6 C-SEM image of basalt after 3 months with extensive weathering of the mineral, and extensive precipitation on the cell wall. This cell may not be viable. Scale bar $=1 \mu \mathrm{m}$.

with living organisms and that the precipitate may interfere with cell metabolism or nutrient transport across the cell wall.

\section{Peat-Bog System}

Field and laboratory microcosm experiments from the oil-contaminated water suggest that microorganisms in a nutrient-limited groundwater destroy silicates to liberate $\mathrm{P}$, and possibly Fe. To test this hypothesis, we constructed laboratory microcosms using a completely different microbial community. Raw peat and peat-water $(\mathrm{pH} \mathrm{4-5)} \mathrm{from} \mathrm{the} \mathrm{Lost} \mathrm{River}$ bog were combined with specific minerals as the sole sources of $\mathrm{Fe}^{(\mathrm{III})}$ and $\mathrm{P}$, to determine changes in iron reduction, release of $\mathrm{P}$, and dissolution of the silicates.

In sterile microcosms at $\mathrm{pH} 4$, anorthoclase releases $\mathrm{P}$ but little $\mathrm{Fe}$ or $\mathrm{Si}$. In infected microcosms where anorthoclase is the sole source of inorganic $\mathrm{P}$ and $\mathrm{Fe}^{(\mathrm{III})}$, the mineral rapidly dissolves, accompanied by iron reduction and release of dissolved silica (Figure 7), but little $\mathrm{P}$ is detected, possibly due to immediate uptake by the microorganisms. (Table 2; Figure 8). When apatite is the sole source of inorganic $\mathrm{P}$, it readily dissolves at the acidic $\mathrm{pH}$ (Figure 9), and $\mathrm{PO}_{4}{ }^{3-}$, concentration is $>2 \mathrm{ppm}$ (nonlimiting conditions). In microcosms where silicates are mixed with apatite, there is no release of silica and no evidence of silicate weathering, presumably because $\mathrm{P}$ is no longer limiting.

When iron minerals such as magnetite are present with apatite, $\mathrm{PO}_{4}{ }^{3-}$ concentrations are $\sim 200 \mathrm{ppb}$ higher than when iron minerals are absent, and $\mathrm{Fe}^{2+}$ concentrations also increase. $\mathrm{P}$ is not released in microcosms in which magnetite is the sole mineral, although the magnetite is heavily colonized (Figure 10); therefore, magnetite does not appear to be a significant source of $\mathrm{P}$. When the bog waters are dominated by methanogenesis, the presence of ferric iron oxide minerals apparently stimulates the iron-reducing population. Under these conditions, we observe increased release of $\mathrm{P}$ into solution and, in the case of anorthoclase, an apparent increase in biomass and accelerated weathering of the silicate matrix. 


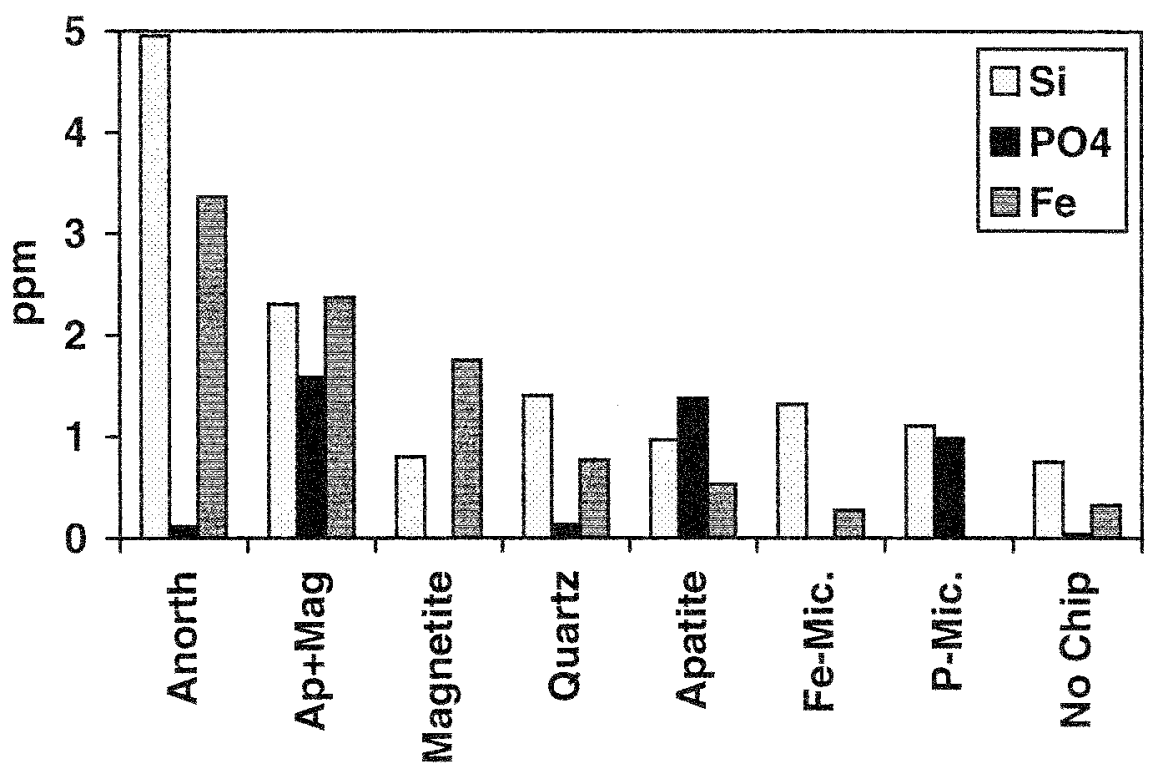

FIGURE 7 Graph of release of silica, orthophosphate, and ferrous iron in bog microcosms. Concentrations are delta values, from the average of tripicate microcosms normalized to a sterile control. All concentrations are expressed in ppm.

\section{Alternative Hypotheses}

These experiments are not definitive, and alternative explanations must be considered. Colonization may simply be controlled by differences in the mineral surface charge, where a positively charged surface would be more readily colonized by negatively charged bacteria due to simple coulombic attraction (Costerton, Marrie, and Cheng 1985). The data, however,

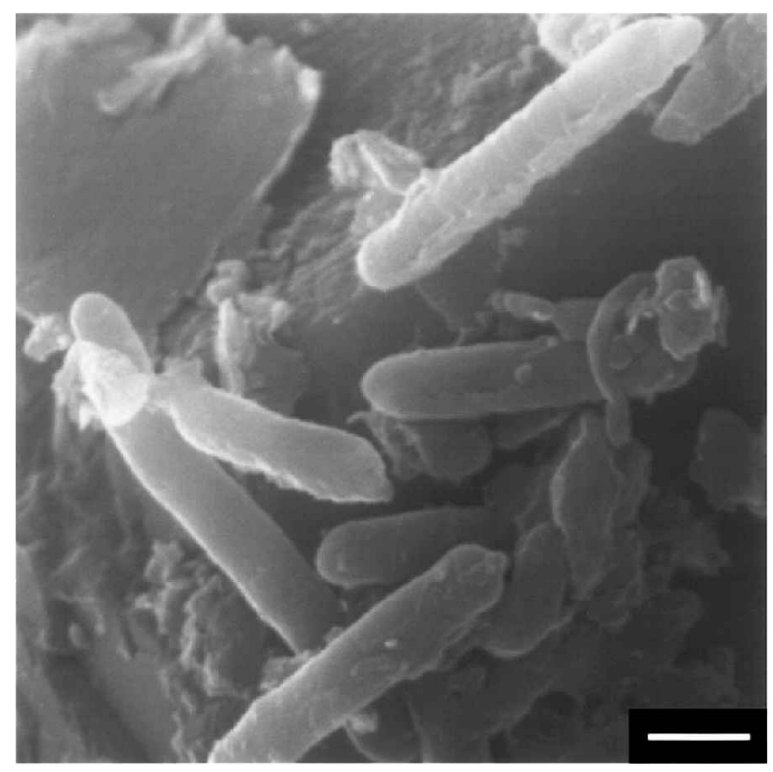

FIGURE 8 C-SEM image of anorthoclase surface from laboratory microcosm containing peat-water, after 6 months. Scale bar $=1 \mu \mathrm{m}$. 


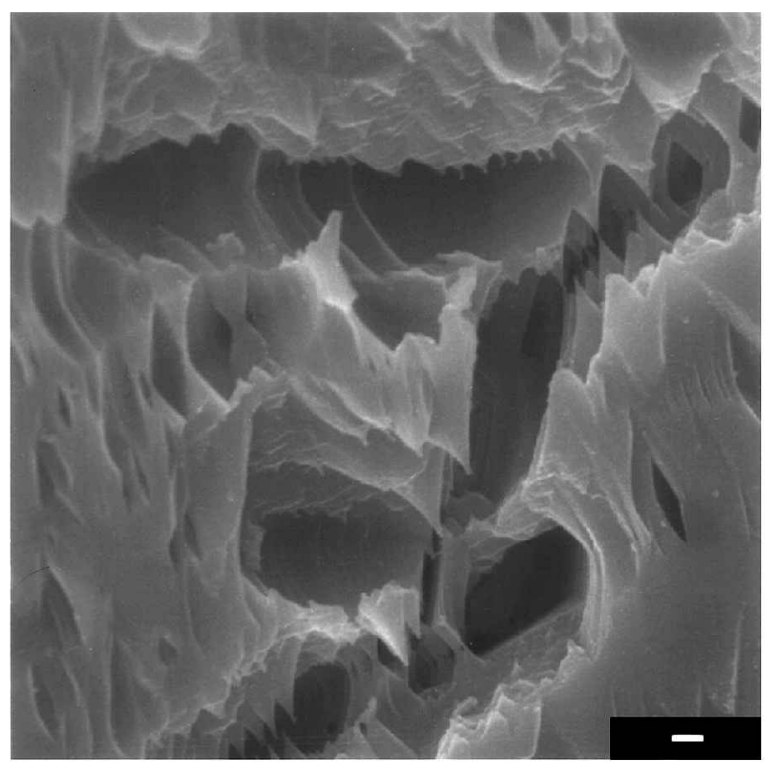

FIGURE 9 C-SEM image of apatite surface from laboratory microcosm containing peatwater, after 6 months. Extensive etch pits are apparent. Scale bar $=1 \mu \mathrm{m}$.

do not support this as the dominant control. Minerals with essentially identical chemistry and surface properties, such as two different microlines, have dramatically different colonization density, with only the P-containing feldspar colonized (Table 2).

The observed differences in weathering rate may simply reflect the fundamental dissolution rate of the selected minerals. Parallel laboratory investigations of the dissolution rate of split samples of the microcosm minerals show that the target feldspars dissolve

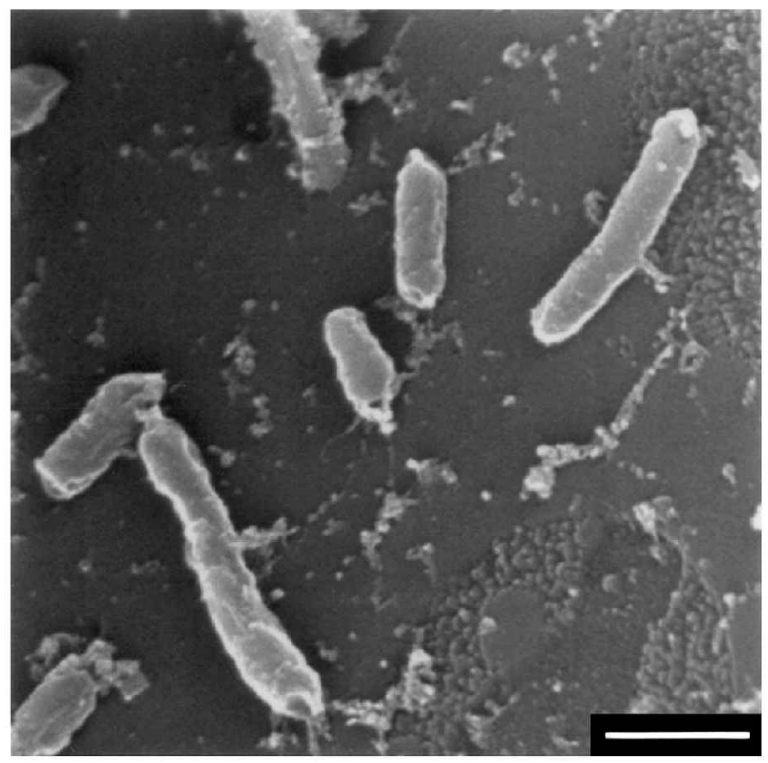

FIGURE $10 \mathrm{C}$-SEM image of magnetite surface from laboratory microcosm containing peat-water, after 6 months. Scale bar $=1 \mu \mathrm{m}$. 
extremely slowly in inorganic solutions between $\mathrm{pH} 4$ and 7. Dissolution rate, however, is greatly accelerated with low concentrations of phenolic acids (intermediates of anaerobic degradation of aromatic hydrocarbons) via a ligand-promoted mechanism. In contrast to the field observations, however, these abiotic experiments show that the relative dissolution rates follow the expected weathering sequence with plagioclase dissolving much more rapidly than microline. The in situ minerals weather in the reverse sequence, related only to colonization, with uncolonized plagioclase stable relative to colonized microline and anorthoclase (Rogers et al. 1998).

\section{IMPLICATIONS}

The biologically mediated destruction of silicate minerals to liberate limiting inorganic nutrients is a fundamental observation of subsurface microbial ecology, and may impact our interpretation of the mineral weathering sequence in the rock record. A basic tenet of sediment diagenesis, the "Goldich Weathering Sequence" (Goldich 1938), states that the most unstable silicate mineral will weather (dissolve) first, with more resistant silicates taking progressively longer to dissolve (from least to most stable), olivine $<$ plagioclase $<$ albite $<$ anorthoclase $\sim$ microcline $<$ quartz. The observed weathering sequence of minerals in an anaerobic, microbially controlled system, however, is almost opposite, with olivine stable with respect to microcline, and the relationship between microbial colonization and weathering rate almost perfectly correlated. This suggests that, in some environments, the indigenous microorganisms may significantly alter weathering patterns as they aggressively scavenge limiting nutrients.

If microorganisms colonize and destroy specific feldspars to release limiting nutrients, then feldspar weathering is not always controlled by simple abiotic kinetics. In this microbial weathering scenario, colonized feldspars containing trace nutrients may weather very quickly and early, leaving behind only a clay residuum and those feldspars without nutritive value. Alternatively, the weathering rate of Ca-containing feldspars through geologic time, a potential part of the global carbon dioxide balance (Berner et al. 1983), may be partly controlled by the trace nutrient potential of each mineral and the local microbial ecology.

\section{References}

Aagaard P, Helgeson HC. 1982. Thermodynamic and kinetic constraints on reaction rates among minerals and aqueous solutions. 1. Theoretical considerations. Amer J Sci 282:237-285.

Abendroth RP. 1970. Behavior of a pyrogenic silica in simple electrolytes. J Colloid Interface Sci 34:591-596.

Albrechtsen JJ. 1994. Bacterial degradation under iron-reducing conditions. In: Hinchee RE, Alleman BC, Hoeppel RE, Miller RN, editors. Hydrocarbon bioremediation. Boca Raton, FL: Lewis Publishers. p 418-423.

Avakyan ZA, Karavaiko GI, Mel'nikova EO, Krutsko VS, Ostroushko YI. 1981. Role of microscopic fungi in weathering of rocks and minerals from a pegmatite deposit. Mikrobiol 50:115-120.

Babu-Khan S, Yeo TC, Martin WL, Duran MR, Rogers RD, Goldstein AH. 1995. Cloning of a mineral phosphate-solubilizing gene from Pseudomonas cepacia. Appl Environ Microbiol 61:972-978.

Baedecker MJ, Cozzarelli IM, Siegel DI, Bennett PC, Eganhouse RP. 1993. Crude oil in a shallow sand and gravel aquifer-III. Biochemical reactions and mass balance modeling in anoxic groundwater. Appl Geochem 8:569-586.

Barker WW, Banfield JF. 1996. Biologically versus inorganically mediated weathering reactions; relationships between minerals and extracellular microbial polymers in lithobiontic communities. Chem Geol 132:55-69.

Barker WW, Hurst VJ. 1992. Bacterial trace fossils in Eocene kaolin of the Huber Formation of Georgia; Phyloderma microsphaleroides. Ichnos 2:55-60. 
Barker WW, Welch SA, Chu S, Banfield JF. 1998. Experimental observations of the effects of bacteria on aluminosilicate weathering. Amer Mineral 83:1551-1563.

Bekins BA, Godsy EM, Warren E. 1999. Distribution of microbial physiologic types in an aquifer contaminated by crude oil. Micro Ecol 37:263-275.

Bennett PC. 1991. The dissolution of quartz in organic-rich aqueous systems. Geochim Cosmochim Acta 55:1781-1797.

Bennett PC, Casey WH. 1994. Organic acids and the dissolution of silicates. In: Pittman ED, Lewan M, editors. The role of organic acids in geological processes. Berlin: Springer-Verlag. p 162-201.

Bennett PC, Siegel DI, Baedecker MJ, Cozzarelli I, Hult M. 1993. The fate of crude oil in a sand and gravel aquifer I. Inorganic geochemistry. Appl Geochem 8:529-549.

Bennett PC, Siegel DI, Hill B, Glaser P. 1990. The fate of silicate minerals in a peat bog. Geology 19:328-331.

Berner RA, Lasaga AC, Garrells RM. 1983. The carbonate-silicate geochemical cycle and its effect on atmospheric carbon dioxide over the past 100 million years. Amer J Sci 283:641-683.

Berthelin J, Belgy G. 1979. Microbial degradation of phyllosilicates during simulated podzolization. Geoderma 21(4):297-310.

Beveridge TJ, Fyfe WS. 1985. Metal fixation by bacterial cell walls. Can J Earth Sci 22:1893-1898.

Beveridge TJ, Murray RGE. 1980. Sites of metal deposition in the cell walls of Bacillus subtilis. J Bact 141:876-887.

Blake RE, Walter LM. 1996. Effects of organic acids on the dissolution of orthoclase at $80^{\circ} \mathrm{C}$ and $\mathrm{pH}$ 6. In: Stillings LL, editor. Chemical and biological control on mineral growth and dissolution kinetics. Amsterdam, Netherlands: Elsevier. p 91-102.

Brantley SL, Stillings L. 1996. Feldspar dissolution at $25^{\circ} \mathrm{C}$ and low pH. Amer J Sci 296:101-127.

Callot G, Maurette M, Pottier L, Dubois A. 1987. Biogenic etching of microfractures in the amorphous and crystalline silicates. Nature 328:147-149.

Casey WH, Bunker B. 1990. Leaching of mineral and glass surfaces during dissolution. In: Hochello MF, Jr, White AF, editors. Mineral-water interface geochemistry. Washington, DC: Mineralogical Society of America. p 397-426.

Chapelle FH. 1993. Ground-water microbiology and geochemistry. New York: Wiley. p 424.

Chapelle FH, Lovely DR. 1990. Rates of microbial activity in deep coastal plain aquifers. Appl Environ Microbiol 56:1865-1874.

Chenu C, Roberson EB. 1996. Diffusion of glucose in microbial extracellular polysaccharide as affected by water potential. Soil Biol Biochem 28:877-884.

Costerton JW, Marrie TJ, Cheng KJ. 1985. Phenomena of bacterial adhesion. In: Savage DC, Fletcher M, editors. Bacterial adhesion. London: Plenum. p 3-43.

Cozzarelli IM, Baedecker MJ, Eganhouse RP, Goerlitz DF. 1994. Geochemical evolution of lowmolecular-weight organic acids derived from the degradation of petroleum contaminants in ground water. Geochim Cosmochim Acta 58:863-877.

Dove PM, Crerar DA. 1990. Kinetics of quartz dissolution in electrolyte solutions using a hydrothermal mixed flow reactor. Geochim Cosmochim Acta 54:955-969.

Drever JI, Vance GF. 1994. Role of soil organic acids in mineral weathering processes. In: Lewan MD, Pittman ED, editors. Organic acids in geological processes. Berlin: Springer-Verlag. p 138-161.

Ehrlich HL. 1996a. Geomicrobiology. New York: Marcel Dekker. p 719.

Ehrlich HL. 1996b. How microbes influence mineral growth and dissolution. Chem Geol 132:5-9.

Eno CF, Reuzer HW. 1955. Potassium availability from biotite, muscovite, greensand, and microcline as determined by growth of Aspergillus niger. Soil Sci 80:199-209.

Ferris FG, Schultze S, Witten TC, Fyfe WS, Beveridge TJ. 1989. Metal interactions with microbial biofilms in acidic and neutral pH environments. Appl Environ Microbiol 55:1249-1257.

Ferris FG, Wiese RG, Fyfe WS. 1994. Precipitation of carbonate minerals by microorganisms: Implications for silicate weathering and the global carbon dioxide budget. Geomicrobiol J 12:1-13.

Fortin D, Ferris FG, Beveridge TJ. 1997. Surface mediated mineral development by bacteria. In: Banfield JK, Nealson, KH, editors. Geomicrobiology: Interactions between microbes and minerals. Washington, DC: Mineralogical Society of America. p 161-180.

Fredrickson JK, Garland TT, Hicks RJ, Thomas JM, Li SW, McFadden SM. 1989. Lithotrophic and heterotrophic bacteria in deep subsurface sediments and their relation to sediment properties. Geomicrobiol J 7:53-66. 
Ghiorse WC, Wilson JL. 1988. Microbial ecology of the terrestrial subsurface. Adv Appl Microbiol 33:107-172.

Glaser P, Bennett PC, Siegel DI, Romanowicz EA. 1996. Palaeo-reversals in ground water flow and peatland development at Lost River, MN. Holocene 6:413-421.

Goldich SS. 1938. A study in rock weathering. J Geol 46:11-58.

Goldstein AH. 1986. Bacterial solubilization of mineral phosphates. Amer J Alt Agri 1:51-57.

Grandstaff DE. 1986. The dissolution rate of forsteritic olivine from hawaiian beach sand. In: Colman SM, Dethier DP, editors. Rates of chemical weathering of rocks and minerals. New York: Academic Press. p 41-60.

Halder AK, Chakrabartty PK. 1993. Solubilization of inorganic phosphate by Rhizobium. Folia Microbiol 38:325-330.

Helgeson HC, Murphy WM, Aagaard P. 1984. Thermodynamic and kinetic constraints on reaction rates among minerals and aqueous solutions II. Rate constants effective surface area, and hydrolysis of feldspar. Geochim Cosmochim Acta 48:2405-2432.

Hellman R. 1994. The albite-water system: Part I. The kinetics of dissolution as a function of $\mathrm{pH}$ at 100, 200, 300 C. EOS, Trans Amer Geophys Union 74:319.

Hiebert FK, Bennett PC. 1992. Microbial control of silicate weathering in organic-rich ground water. Science 258:278-281.

Hooper PR, Hawkesworth CJ. 1993. Isotopic and geochemical constraints on the origin and evolution of the Columbia River Basalt. J Petrology 34:1203-1246.

Huang CP. 1981. The surface acidity of hydrous solids. In: Anderson MA, Rubin AJ, editors. Adsorption of inorganics at solid-liquid interfaces. Ann Arbor, MI: Ann Arbor Science. p 183-217.

Huang WH, Longo JM. 1992. The effect of organics on feldspar dissolution and the development of secondary porosity. Chem Geol 98:271-292.

Jansson M. 1987. Anaerobic dissolution of iron-phosphorus complexes in sediment due to the activity of nitrate-reducing bacteria. Microb Ecol 14:81-89.

Jones D, Wilson MJ, McHardy WJ. 1981. Lichen weathering of rock-forming minerals: application of scanning electron microscopy and microprobe analysis. J Microsc 124:95-104.

Jongmans AG, van Breeman N, Lundstrom U, van Hees PAW, Finlay RD, Srinivasan M, Unestam T, Giesler R, Melkerud P-A, Olsson M. 1997. Rock-eating fungi. Nature 389:682-683.

Kinraide TB. 1991. Identity of rhyzotoxic aluminum species. Plant and Soil 134:167-178.

Kirkpatrick RJ. 1981. Kinetics of crystallization of igneous rocks. In: Lasaga AC, Kirkpatrick RJ, editors. Kinetics of geochemical processes. Washington, DC: Mineralogical Society of America. p 1-81.

Konhauser KO, Ferris FG. 1996. Diversity of iron and silica precipitation by microbial mats in hydrothermal waters, Iceland: Implications for Precambrian iron formations. Geology 24:323326.

Laidler KJ. 1987. Chemical kinetics. New York: Harper \& Row.

Lasaga AC. 1981. Rate laws of geochemical reactions. In: Lasaga AC, Kirkpatrick RJ, editors. Kinetics of geochemical processes: Reviews in mineralogy 8:321-395.

Lovley DR, Baedecker MJ, Lonergan DJ, Cozzarelli IM, Phillips EJP, Siegel DI. 1989. Oxidation of aromatic contaminants coupled to microbial iron reduction. Nature 339:297-300.

Lovley Dr, Chapelle FH. 1995. Deep subsurface microbial processes. Rev Geophys 33:365-381.

Madigan MT, Martinko JM, Parker J. 1997. Brock biology of microorganisms. Englewood Cliffs, NJ: Prentice-Hall. 986 p.

Madsen EL, Ghiorse WC. 1993. Ground water microbiology: subsurface ecosystems processes. In: Ford T, editor. Aquatic microbiology: An ecological approach. Cambridge, MA: Blackwell Scientific. p 167-214.

Malinovskaya IM, Kosenko LV, Votselko SK, Podgorskii VS. 1990. Role of Bacillus Mucilaginosus polysaccharide in degradation of silicate minerals. Mikrobiol 59:49-55.

Murphy F, Herkelrath WN. 1996. A sample-freezing drive shoe for a wire-line piston core sampler. Ground Water Monitoring and Remediation 16:86-90.

Palmer RJJ, Siebert J, Hirsch P. 1991. Biomass and organic acids in sandstone of a weathered building: production by bacterial and fungal isolates. Micro Ecol 21:253-261.

Pedersen K. 1993. The deep subterranean biosphere. Earth Sci Revi 34:243-260. 
Revesz K, Coplen TB, Baedecker MJ, Glynn PD, Hult MF. 1995. Methane production and consumption monitored by stable $\mathrm{H}$ and $\mathrm{C}$ isotope ratios at a crude oil spill site, Bemidji, Minnesota. Appl Biochem 10:505-516.

Rogers JR, Bennett PC, Choi WJ. 1998. Feldspars as a source of nutrients for microorganisms. Amer Mineral 83:1532-1540.

Rooney-Varga JN, Anderson RT, Fraga JL, Ringelberg D, Lovely DR. 1999. Microbial communities associated with anaerobic benzene degradation in a petroleum-contaminated aquifer. Appl Env Microbiol 65:3056-3063.

Sharp M, Parkes J, Cragg B, Fairchild IJ, Lamb H, Tranter M. 1999. Widespread bacterial populations at glacier beds and their relationship to rock weathering and carbon cycling. Geology 27:107110.

Silverman MP, Munoz EF. 1970. Fungal attack on rock: solubilization and altered infrared spectra. Science 169:985-987.

Stillings LL, Brantley SL. 1995. Feldspar dissolution at $25^{\circ} \mathrm{C}$ and $\mathrm{pH}$ 3: Reaction stiochiometry and the effect of cations. Geochim Cosmochim Acta 59:1483-1496.

Stillings LL, Drever JI, Brantley SL, Sun Y, Oxburgh R. 1996. Rates of feldspar dissolution at pH 3-7 with 0-8 mM oxalic acid. Chem Geol 132:79-90.

Surdam RC, MacGowan DB. 1988. Oilfield waters and sandstone diagenesis. Appl Geochem 2:613620.

Tadros TF, Lyklema J. 1968. Adsorption of potential-determining ions at the silica-aqueous electrolyte interface and the role of some cations. J Electroanal Chem 17:267-275.

Ullman WJ, Kirchman DL, Welch SA, Vandevivere P. 1996. Laboratory evidence for microbially mediated silicate mineral dissolution in nature. Chem Geol 132:11-17.

Urrutia MM, Beveridge TJ. 1994. Formation of fine-grained metal and silicate precipitates on a bacterial surface (Bacillus subtilis). Chem Geol 116(3-4):261-280.

Urrutia MM, Beveridge TJ. 1995. Formation of short-range ordered aluminosilicates in the presence of a bacterial surface (Bacillus subtilis) and organic ligands. Geoderma 65:149-165.

Vandevivere P, Bevaye P. 1993. Improved preservation of bacterial exopolymers for scanning electron microscopy. J Micros 167:323-330.

Vandevivere P, Welch SA, Ullman WJ, Kirchman DL. 1994. Enhanced dissolution of silicate minerals by bacteria at near-neutral $\mathrm{pH}$. Microb Ecol 27:241-251.

Welch SA, Barker WW, Banfield JF. 1999. Microbial extracellular polysaccharides and plagioclase dissolution. Geochim Cosmochim Acta 63(9):1405-1419.

Welch SA, Ullman WJ. 1993. The effect of organic acids on plagioclase dissolution rates and stoichiometry. Geochim Cosmochim Acta 57:2725-2736.

Wollast R. 1967. Kinetics of the alteration of k-feldspar in buffered solutions at low temperature. Geochim Cosmochim Acta 31:635-648.

Wollast R, Chou L. 1992. Surface reactions during the early stages of weathering of albite. Geochim Cosmochim Acta 56:3113-3121. 